\title{
NCD Diamond Semiconductor System for Advanced Power Electronics Systems Integration
}

CRADA Report

Nanoscience and Technology Division, Argonne National Laboratory 


\title{
About Argonne National Laboratory
}

Argonne is a U.S. Department of Energy laboratory managed by UChicago Argonne, LLC under contract DE-AC02-06CH11357. The Laboratory's main facility is outside Chicago, at 9700 South Cass Avenue, Argonne, Illinois 60439. For information about Argonne

and its pioneering science and technology programs, see www.anl.gov.

\section{DOCUMENT AVAILABILITY}

Online Access: U.S. Department of Energy (DOE) reports produced after 1991 and a growing number of pre-1991 documents are available free via DOE's SciTech Connect (http://www.osti.gov/scitech/)

\author{
Reports not in digital format may be purchased by the public from the \\ National Technical Information Service (NTIS): \\ U.S. Department of Commerce \\ National Technical Information Service \\ 5301 Shawnee Rd \\ Alexandria, VA 22312 \\ www.ntis.gov \\ Phone: (800) 553-NTIS (6847) or (703) 605-6000 \\ Fax: (703) 605-6900 \\ Email: orders@ntis.gov
}

Reports not in digital format are available to DOE and DOE contractors from the Office of Scientific and Technical Information (OSTI):

U.S. Department of Energy

Office of Scientific and Technical Information

P.O. Box 62

Oak Ridge, TN 37831-0062

www.osti.gov

Phone: (865) 576-8401

Fax: (865) 576-5728

Email: reports@osti.gov

Disclaimer

This report was prepared as an account of work sponsored by an agency of the United States Government. Neither the United States Government nor any agency thereof, nor UChicago Argonne, LLC, nor any of their employees or officers, makes any warranty, express or implied, or assumes any legal liability or responsibility for the accuracy, completeness, or usefulness of any information, apparatus, product, or process disclosed, or represents that its use would not infringe privately owned rights. Reference herein to any specific commercial product, process, or service by trade name, trademark, manufacturer, or otherwise, does not necessarily constitute or imply its endorsement, recommendation, or favoring by the United States Government or any agency thereof. The views and opinions of document authors expressed herein do not necessarily state or reflect those of the United States Government or any agency thereof, Argonne National Laboratory, or UChicago Argonne, LLC. 


\section{NCD Diamond Semiconductor System for Advanced Power Electronics Systems Integration}

\section{CRADA Report}

prepared by

Anirudha Sumant

Nanoscience and Technology Division, Argonne National Laboratory

Industry Partner

Adam Khan

AKHAN Semiconductor, Inc.

2300 Barrington Road, Suite 400

Hoffman Estates, IL 60195

July 22, 2016 


\section{Non Proprietary \\ Final CRADA Report}

Date: $\quad \underline{07 / 22 / 2016}$

CRADA Number: $\quad \underline{1400701}$

CRADA Title: $\quad$ NCD Diamond Semiconductor System for Advanced Power Electronics Systems Integration

CRADA Start/End Date: 12/5/2014 to $\underline{04 / 15 / 2016}$

Argonne Dollars: $\quad \$ 0$

Participant Dollars: $\quad \$ 175,859.34$ cost, Authorized funds $(\$ 212,105)$

Argonne PI: $\quad$ Anirudha Sumant

Participant(s):

Adam Khan

Name $\quad$ Participant Dollars

AKHAN Semiconductor, Inc. 2300 Barrington Road, Suite 400, Hoffman Estates, IL 60195

Complete Address

$\overline{\text { Name }} \quad \overline{\text { Participant Dollars }}$

Complete Address

$\overline{\text { Name }} \quad \overline{\text { Participant Dollars }}$

Complete Address

DOE Program

Manager:

Summary of Major Accomplishments:

The integration of 2D materials such as molybdenum disulphide (MoS2) with diamond (3D) was achieved by forming an heterojunction between these two materials and its electrical performance was studied experimentally. The device charactertics did show good rectifying nature when p-type single crystal diamond was integrated with n-type MoS2. These results are very encouraging indicating possible applications in semiconductor electronics, however further studies are required for a detailed understanding of the transport phenomena at the MoS2/diamond interface. 
Summary of Major Accomplishments:

*The CRADA was terminated by Argonne on April 15, 2016.

*The original scope of the work (SOW) was modified significantly as per discussion with Akhan semiconductor Inc.

Summary of Technology Transfer Benefits to Industry:

The work performed under this CRADA produced a new technology of integarting 2D materials with diamond to fabricate heterojunction devices that could be utilized in semiconductor electronics without the traditional approach of forming p-n junction devices through well controlled chemical vapor deposition process. Although the study is not complete (since the project was terminated), this approach of integrating 2D materials with 3D materials could lead to some interesting device concepts in semiconductor electronics

Other Information/Results: (Papers, Inventions, Software, etc.)

ANL invention disclosure ANL-IN-15-097 "Fabrication of p-n junction devices through diamond/2D materials integration"

*A separate file contaning the results obtained along with the description is attached. The ANL presentation of the patent disclosure is also attached 


\section{Argonne}

Nanoscience and Technology Division

Argonne National Laboratory

9700 South Cass Avenue, Bldg. 440

Argonne, IL 60439

www.anl.gov 